\title{
Colour idioms: phraseological units with the colour designation component
}

\section{Marharyta Alsultan}

English Department, College of Education and Languages, Lebanese French University, Erbil, Kurdistan Region, Iraq

alsultan.Ifu@gmail.com

\section{ARTICLE INFO}

\section{Article History:}

Received: 5/7/2020

Accepted:29/9/2020

Published: Winter 2020

\section{Keywords:}

Phraseological unit, Idiom, Colour designation component, Semantic Analysis, Componential Analysis, Stylistic expression, Lexicology, Conceptual Analysis.

\section{Doi:}

10.25212/Ifu.qzj.5.4.28

\begin{abstract}
This research aims at studying phraseological units (idioms) that contain in their semantics an element of colour designation. Emphasis is done on the analysis of theoretical data on the subject; determining the role and meaning of phraseological units in the English language. The author has considered colour as a component of the cultural connotation of phraseological units, has classified and disclosed the meaning of phraseological units with a colour designation component.

Undoubtedly, colour is of great importance in the life of a modern person. It is difficult to imagine a person's life without colour. It can be viewed from various perspectives: artistic and aesthetic, psychological, physical, social, environmental and many others. Colour opens up a special world to us, filling it with an amazing opportunity to admire the beauty of everything that surrounds us. It helps us to get additional information about various people, objects, surroundings; evokes special feelings, influences our consciousness, leads to reflections.

Human beings are characterized by constant desire to name the objects and phenomena that surround them, acquiring individual, historical and cultural experience. The colour perception of the world is reflected in the lexical and phraseological systems of the language. The emergence of phraseological units is directly related to the formation of metaphorical meanings for colour designations, and the symbolism of colour had a decisive influence on the
\end{abstract}


emergence of metaphorical meanings of adjectives - colour designations.

Therefore, for linguists colour designation is one of the most popular lexical groups. Different attitudes to this or that shade are reflected in figurative expressions, idioms and sayings existing in the language. After all, they accumulate socio-historical, intellectual, emotional information of a specific national character. Phraseological units are quite common means of expressing images. They help to perceive information in a different way, influencing the human imagination.

\section{INTRODUCTION}

In the language of each nation there are stable figurative expressions that are reproduced in speech like a word, and are not created in the process of communication or writing a text. Such stable phrases are called phraseological units, phraseological phrases or phrases, which together form the phraseological unit of the language or phrases. Phrasemics is the greatest treasury and the enduring value of any language.

The role of colour perception of the world by a person is difficult to overestimate. Through colour (clothing, national symbols, customs), one can determine the mood, emotions and even important events that are happening at that moment in a person's life. The phenomenon of colour has become the subject of study for many linguists, psychologists, which can be explained by the importance of this phenomenon in people's lives. On the basis of colour customs, for example, one can trace the historical formation of the people.

These factors can explain the choice of the research topic. Colour carries important information separately from language, but, being a part of language units, including stable ones, this component is endowed with more important significance and acquires a certain symbolism.

This research aims at studying English phraseological units containing the colour designation component from the perspective of semantic analysis, determining their 


\section{QALAAI ZANISTSCIENTIFIC JOURNAL \\ A Scientific Quarterly Refereed Journal Issued by Lebanese French University - Erbil, Kurdistan, Iraq \\ Vol. (5), No (4), Winter 2020 \\ ISSN 2518-6566 (Online) - ISSN 2518-6558 (Print)}

place in the phraseological fund as a whole. In the course of this paper, the following tasks are set:

- to explore the theoretical basis of phraseology;

- to identify the features of phraseological units containing in their composition colour designation components and to perform semantic analysis of them.

Recently, social, political and economic upheavals have led to the migration of people, their resettlement, which led to a clash of cultures. The whole world is divided into its own, united by language and culture, and strangers who do not know another language and another culture. English has become the main international means of communication; it is used by millions of people. Despite the large number of works devoted to this problem, it remains in the spotlight for many reasons.

Therefore, the relevance of the research is determined by the cultural value and prevalence of idiomatic expressions in modern English language.

\section{LITERATURE REVIEW}

A lot of attention is paid to the study of the linguistic aspect of the problem of colour designation in the works of scientists from different countries and languages. Highlighting colour designation as a special linguistic-conceptual category, in them colour designation is considered on the material of different languages in cognitive and sociocultural aspects (E. Sapir and B. Wharf, Berlin V. and Kay R. (1949), Kay R., Berlin B., Maffi L., Merrifield W. (2003), Saunders B., Van Brakel (1997), Bernstein (1973), Brown (1976), Collier (1976), Hickerson (1971), Durbin (1972), Conklin (1973), Bakhilina N. B., Kulpina V. G., Matveev B. I., Pemyakin F.N., Chumak-Zhun I. ।.).

The problem of colour designation was widely considered in the comparative typological aspect. Based on the material of various comparable languages, it was developed by such researchers as V. A. Yurik, A. S. Pankratiev, G. E. Astramskayte, M. N. Ganikhodzhaev, A. P. Vasilevich, Y. N. Skokan, R. Alimpieva V., Basharina A.K., Bedoidze L.G., Belyaeva N.D., Bonderman D.A., Bragina A.A., Burlak A.I., Granovskaya L.M., Matveev B. I Chumak-Zhun I.I., Shemyakin F.N. Comparative typological 


\section{QALAAI ZANISTSCIENTIFIC JOURNAL \\ A Scientific Quarterly Refereed Journal Issued by Lebanese French University - Erbil, Kurdistan, Iraq \\ Vol. (5), No (4), Winter 2020 \\ ISSN 2518-6566 (Online) - ISSN 2518-6558 (Print)}

research also allows one to most fully identify the features of linguistic conceptualization of colour by representatives of different linguistic cultures.

\section{English Phraseology: Characteristics, Key Features}

Phraseology - (from the Greek "phrasis" and "logos") is a science that studies stable combinations of words - phraseological units. The term "phraseology" was introduced by Swiss scientist Sh. Bally, where he understood this science as that which is studying connected combinations. Despite the fact that different authors name these units differently, each definition emphasizes the essence of phraseologism their semantic unity, stability of meaning. Stability, as a rule, is characterized by the reproduction of the existing combination in the finished form. A. Kunin identifies five types of resistance of phraseological units: sustainability, structural-semantic stability, semantic stability, lexical and syntactic stability (Kunin, 1996).

The first type of stability is that phraseological unit is a unit of language, and is not formed by the speaker in the flow of speech. As a rule, they are formed as a result of memorizing by the native speakers of a word combination in view of its originality and conciseness, after which the individual author's phrase becomes public domain and replenishes the people's language treasury.

Structural - semantic stability of phraseological units means the impossibility of creating similar phraseological units using this model. By "semantic invariance" is meant the stability of meaning, the presence of a similar meaning in phraseological variants, as well as the presence of a semantic invariant with any changes in a phraseological unit. Speaking of lexical stability, A. Kunin had in mind "the irreplaceability of components" (Kunin, 1996:115).

For example, the inclusion of pronouns in the phraseological unit is not a violation of this type of stability, since these components can serve to clarify, but not to change the semantics of the phraseological unit. So, the phraseology "hold horses" (to stop worrying, not to get nervous) is often used with a possessive pronoun, which does 
not affect the meaning ("hold her horses", "hold your horses"), but only performs a clarifying function.

\section{The main features of the phraseological unit}

Specific features of phraseologisms, as a rule, come to light as a result of comparison with another type of speech units - free phrases.

The main sign of any phraseological unit is its reproducibility in the finished form. In speech, ready-made units are used that make up the speaker's vocabulary, that is, the mechanism for reproducing existing language material is triggered. At the slightest violation of the design or omission of one of the elements, a complete loss of meaning or transformation into a free phrase is possible.

The second sign of phraseology is the stability of component composition. Replacing one of the elements, as a rule, leads to the loss of a unique meaning, that is, the phraseological unit also turns into a free combination. Minor substitutions are allowed (pronouncing the right pronoun, plural).

Separation of the phraseological unit lies in its dual nature. On the one hand, phraseologism consists of two or more words that are morphologically structured, and on the other hand, from the point of view of semantic integrity, any phraseological unit is equated to one word, since when considering the meanings of phraseological elements separately, it is easy to notice that their meanings are slightly darkened or completely lost (Komissarov, 2007). Thus, any phraseological unit has a number of differential features. Their number is large, and along with the main features, a number of others can be distinguished, for example, connotation, idiomaticity.

\section{Semantic analysis of phraseological units}

Semantics is a brunch of linguistics that studies the meaning of language units. Semantic analysis is used as a study tool. In the late nineteenth and early twentieth centuries, semantics was often also called semasiology (Sharonov 2005). 


\section{QALAAI ZANISTSCIENTIFIC JOURNAL \\ A Scientific Quarterly Refereed Journal Issued by Lebanese French University - Erbil, Kurdistan, Iraq \\ Vol. (5), No (4), Winter 2020 \\ ISSN 2518-6566 (Online) - ISSN 2518-6558 (Print)}

Semantics is an activity that is to clarify the meaning of human statements. Its purpose is to reveal the structure of thought hidden behind the external form of language. The main focus of modern semantics is the semantic representation: instead of talking about meanings (and changes in meanings), it seeks to model them and present them in the form of explicit formulas. Currently, it is widely believed that the basis of semantics should be the modeling of meanings, so that for natural language to be suitable as a semantic metalanguage, it must be appropriately "ordered". Semantic analysis is inevitably associated with simplification. The essence of the problem is to select the smallest possible part of the natural language and, in particular, to determine the minimum list of words and expressions that would be sufficient to represent the meanings of all other words and their relationship.

The first modern linguist, to focus on finding the elementary semantic units, was, apparently, Edward Sapir (1921), who wrote in the early 30-ies a series of works devoted to logical relations in the language: "Universality", "Expression of endpoint relations in English, French and German" (together with Morris Swadesh) and "Degrees. Essays on Linguistics".

Meanwhile, in the forties and fifties, due to the research of scientists such as Louis Hjelmslev and Holger Sorensen, a deeper and more distinct understanding of the purely theoretical aspects of the search for elementary meanings was achieved. Hjelmslev proposed distinguishing elementary components, which he called "figures", at two levels - content and expression. Sorensen advanced Hjelmslev's analysis one more step further, replacing the somewhat vague concept of "figures" with the concept of undetectable signs.

In 1963, Katz and Fodor made an attempt to introduce the component analysis into the generative grammar, a very important consequence of this attempt was that the ranks of previously quite a few researchers interested in component semantic analysis were replenished due to the influx of a large number of generativists. It fell to Manfred Bierwisch to make the first concrete semantic analysis, carried out in the framework of the corresponding practical ideas. 


\section{QALAAI ZANISTSCIENTIFIC JOURNAL \\ A Scientific Quarterly Refereed Journal Issued by Lebanese French University - Erbil, Kurdistan, Iraq \\ Vol. (5), No (4), Winter 2020 \\ ISSN 2518-6566 (Online) - ISSN 2518-6558 (Print)}

Among modern researches in the field of component semantic analysis, a special place is occupied by the works of Yu. Apresyan. He considers semantic analysis as a kind of translation from a natural language into a "semantic" language, the "words" of which are what he calls "elementary meanings".

A fundamental and carefully developed research plan was the first to be proposed by Andrei Boguslavsky in 1965-1966. In accordance with the central position of Boguslavsky's program, involuntary and universal elementary units of content should be sought among elements of the most complete semantic interpretations of expressions, in other words, in their indefinable components. These indefinable elements, obtained through the full interpretation of expressions, according to Boguslavsky, should represent those "ultimate components of the world" that have long been the subject of philosophers' searches (Vezhbitskaya, 1999).

Componential analysis is one of the ways of formalizing or giving absolute accuracy to semantic relationships between tokens. As the name of the method shows, it consists in decomposing the meaning of the token into its component parts (components). An alternative term for componential analysis is lexical decomposition (Cowie, 1998).

The semantic relations can be of two types: substitutional and combinatorial (or, in more familiar to linguists, Saussure's terms, - paradigmatic and syntagmatic). Substitutional relationships are relationships that exist between interchangeable members of the same grammatical category; combinatorial relations usually exist, although not necessarily, between expressions of different grammatical categories (for example, nouns and adjectives, between verbs and adverbs, etc.), which can be combined into grammatically correctly constructed combinations (or constructions). For example, a substitutional relationship (of a specific kind) exists between the nouns "bachelor" and "spinster", while a relationship existing between the adjective "unmarried" and nouns "man" and "woman", is combinatorial. 
Seliverstova under componential analysis refers to the process of splitting the meaning into component parts, the isolation of which is due to the relation of elements within a single meaning (the presence of more general and more private elements, i.e., hierarchical organization), as well as the relation of this meaning to the meanings of other language units (congruence or neutralization of the elements of the upper levels and the congruence of the differentiating features of the lower levels) (Seliverstova, 2004:34).

I. Kobozeva defines componential analysis as a representation of the meaning of words in the form of elementary components of meaning.

The assumption that the meaning of each unit of the language (including words) consists of a set of semantic components is one of the main hypotheses on which the method of componential analysis is based.

A number of terms are used to denote the minimum unit of meaning: seme, semantic differential attribute, semantic factor, semantic primitive, semantic atom, content figure.

Many words can be described semantically only as part of expressions, large in volume, phrases or sentences. Such an expression is called a sentimental or situational form. The description of the meaning of words in sentimental forms creates the necessary bridge through which we move from the field of lexical semantics to the field of sentence semantics. The meaning of the word should be presented in the form of a structure consisting of elements of meaning and syntactic relations connecting them.

\section{METHODOLOGY}

The following research methods were applied in the work:

- the main research method is a descriptive method;

- a continuous sampling method was used in selecting data of phraseological units with colour designation component. 


\section{QALAAI ZANISTSCIENTIFIC JOURNAL \\ A Scientific Quarterly Refereed Journal Issued by Lebanese French University - Erbil, Kurdistan, Iraq \\ Vol. (5), No (4), Winter 2020 \\ ISSN 2518-6566 (Online) - ISSN 2518-6558 (Print)}

- a method of component analysis, the essence of which is to interpret the values of the units under study through a set of semantic components inherent in them;

- a method of linguistic description, involving the interpretation of the characteristics of the studied language units;

- the method of the field approach, allowing to distinguish both central, or nuclear, and peripheral components in the structure of phraseology with a colour designation component; as well as analysis by distinguishing thematic categories, the distribution of phraseological units into phraseological semantic subgroups on the basis of their identification with individual lexemes, phrases or detailed descriptions in lexicographic sources;

- a conceptual analysis method aimed at exploring the content of the concept of "color designation" in English.

\section{DATA ANALYSIS AND DISCUSSIONS}

For this study, English idioms were selected by the continuous sampling method, in which the colours of palette are included.

1) White:

- White coffee, white tea - tea / coffee with milk.

The word "cream" in this idiom is replaced by the word "white" based on colour. The meaning of the second component does not change. For example: I prefer to drink white coffee in the morning.

- A white lie - a lie to save.

In most nations, the colour white symbolizes purity, light, holiness, goodness, etc. In the above idiom, the word "white" is used precisely with these connotations. Thus, it softens the negative connotation of the word "false". For example: I know it was a white lie. 


\section{QALAAI ZANISTSCIENTIFIC JOURNAL \\ A Scientific Quarterly Refereed Journal Issued by Lebanese French University - Erbil, Kurdistan, Iraq \\ Vol. (5), No (4), Winter 2020 \\ ISSN 2518-6566 (Online) - ISSN 2518-6558 (Print)}

- To show a white feather - show fear, frighten.

In this example, the "white feather" is used in association with the "white flag", which means surrender or a break for negotiations. But despite the fact that the "white flag" is not always bad, the presented idiom carries a clearly negative assessment. For example: Young soldier showed a white feather.

2) Purple:

- To be born in purple - to be born in a noble family, i.e. to have a noble origin.

Violet is considered the royal colour in England, so it contains a connotation of wealth, power and nobility. For example: The princess was born in purple.

4. Black:

- Black look - a gloomy, menacing look.

Just like white in most countries is associated with good, black means evil. In this idiom, the neutral word "look" takes on a negative connotation, as it is determined by black colour. For example: She has black look.

- Black sheep - strange.

The "black sheep" in English is a well-established expression denoting a person who is very different from others, often uncommunicative, who has some serious flaw. In this case, the word "black" is used as a qualifier for the word "sheep" to emphasize that this phenomenon is abnormal. For example: I feel myself as a black sheep.

4) Blue:

- To feel blue, to look blue - to be sad, sad.

Blue in England is associated with sadness and longing. In the above example, the word "blue" is used not in the main colour meaning, but in the meaning for state of being. For example: I am feeling blue. He is as blue as the devil. (gloomy). 
- Out of the blue - suddenly, completely unexpectedly.

In this case, "blue" is used as a synonym for purity, cloudlessness, calm. For example: And out of the blue he asked me about my family.

- Blue-eyed boy - favourite.

Blue eyes are considered beautiful not only in England, but also in many other countries. Moreover, this eye colour in England is rarely found in its pure form. For example: He's the director's blue-eyed boy!

5) Green:

- The green-eyed monster - is a jealous man.

In English culture, green is associated with jealousy and envy. For example: My neighbour is the green-eyed monster.

- To be green about the gills - to be very pale. Green is also associated with painful pallor. For example: Suddenly a student is green about the gills.

- To have green fingers - to be a good gardener.

In this idiom, green represents plants. Thus, "green fingers" are not translated literally, but imply that a person knows how to use his hands to grow plants. For example: Jane has green fingers.

- Green as grass - completely green (inexperienced).

Such an idiom is based on a natural phenomenon. As you know, most fruits at the initial stage are green, and only after ripening do they acquire their colour. By this association, the above idiom arose. For example: Young driver was green as grass.

- have got the green light - have permission. 
This idiom owes its creation to such a miracle of technology as a traffic light, in which green means permission to continue driving. For example: Finally we have got the green light and our parents will buy us a dog.

\section{Grey:}

- Grey area - is something that is not so easy to define and therefore difficult to deal with.

In this case, the colour properties are transferred to the described item. Grey properties are inconspicuousness, uncertainty, obscurity. For example: The law concerning e-mail is still a gray area in some countries.

8. Red:

- To see red - get angry.

It is believed, however, erroneously that when a bull sees a red colour, it becomes very angry, aggressive. People quickly adopted this "feature" of the behaviour of a bull into the arsenal in order to describe the degree of anger of other people. For example: It really makes me see red when I see many trees are thoughtlessly cut down by people.

- To put out the red carpet.

This expression is used in a figurative sense. For example, if a student won the Olympics, the teacher can jokingly suggest "To put out the red carpet" (spread the red carpet). A student traveling to his parents on vacation can also use this phrase. In such situations, the idiom means welcome. The meaning of red for Europeans is twofold - it is a danger, a threat, and at the same time a holiday.

- A red letter day - red calendar day, holiday (David, 1986). 


\section{QALAAI ZANISTSCIENTIFIC JOURNAL \\ A Scientific Quarterly Refereed Journal Issued by Lebanese French University - Erbil, Kurdistan, Iraq \\ Vol. (5), No (4), Winter 2020 \\ ISSN 2518-6566 (Online) - ISSN 2518-6558 (Print)}

This expression is based on the rule to circle the holidays on the calendar. For example: It's a red letter day tomorrow in the company. It's our fiftieth birthday!

Semantics is a section of linguistics that studies the meaning of language units. As a study tool, semantic analysis is used.

A semantic analysis of English idioms confirmed that in most cases such expressions are based on associative connections and concepts of human thinking. Here are some of them:

1) For most peoples, the white colour symbolizes purity, light, holiness, goodness, etc.

2) Just as white in most countries is associated with good, black means evil.

3) Violet is considered the royal color in England, so it contains a connotation of wealth, power and nobility.

4) The blue color in England is associated with sadness and longing.

5) In English culture, green is associated with jealousy and envy.

6) The meaning of red for Europeans is two facets - it is a danger, a threat, and at the same time a holiday.

\section{CONCLUSION}

Stable units with a colour component occupy an important place in the English phraseological foundation. Due to the fact that the colour naming system is widely developed, each colour has broad semantics and is used to describe a variety of environmental phenomena. Often, semantic oppositions are formed between the individual meanings of colours, which can be easily traced on the example of phraseological units containing adjectives black and white. So, the phraseological unit (phraseological unit) is an unmodeled phrase associated with semantic unity. In speech, such a unity is not created, but is reproduced in a finished form (not modeled) and functions as a single member of a sentence. Thus, units of the phraseological foundation are a special, specific layer of vocabulary with a diverse structure, performing different functions in speech and endowed with special semantic 


\section{QALAAI ZANISTSCIENTIFIC JOURNAL \\ A Scientific Quarterly Refereed Journal Issued by Lebanese French University - Erbil, Kurdistan, Iraq \\ Vol. (5), No (4), Winter 2020 \\ ISSN 2518-6566 (Online) - ISSN 2518-6558 (Print)}

cohesion. The semantics of phraseological units is very closely related to the context and, as a rule, are endowed with an expressive component of meaning. Phraseological units form an open flexible system, with the possibility of moving combinations closer to or further from the core, up to the exit from the phraseological fund.

As for the idiom, it is considered as a combination of language units, the meaning of which does not coincide with the value of its elements. Idioms are products of the secondary nomination. They are formed on the basis of an image enclosed in an internal form. Firstly, the internal form (just its image) motivates semantics, and secondly, it is the source of the cultural connotation.

A semantic analysis of English idioms confirmed that in most cases such expressions are based on associative connections and concepts of human thinking.

\section{REFERENCES:}

Berlin, B. \& Kay, P. (2008). Basic Color Terms: their Universality and Evolution. Berkeley: University of California Press.

Chernysheva I.I. (1974). Tekstoobrazuyushchiye potentsii frazeologicheskih yedinits. Moskva: Lingvistika teksta.

Cowie, A.P. (1998). Phraseology - Theory, Analysis, and Applications. Oxford: Clarendon Press.

David, G. (1986). Dictionary of English Idioms. Oxford: Penguin books.

Fedulenkova T. (1999). Diachronic Approach to the Study of Communicative Phraseological

Units. Northern Development and Sustainable Livelihoods: Towards a Critical Circumpolar Agenda. Volume 6. Pp. 41-42.

Fedulenkova T. (2000). Development of English proverbs. Sociolinguistic Symposium 2000: Abstracts. P. 172.

Fedulenkova T. (2003). A new approach to the clipping of communicative phraseological units. European Society for the Study of English. Volume 36. - Pp. 11-22.

Gavrin S.G.(1974). Frazeologiya sovremennogo russkogo yazyka. Perm: Raduga.

Gläser R. (2009). Phraseological Units in Standard Varieties of English as Indicators of Cultural Identity. Cross-Linguistic and Cross-Cultural Approaches to Phraseology. Volume 9. Pp. 86-99.

Kunin A.V. (1996). Kurs frazeologii sovremennogo angliyskogo yazyka. Moscow: AST. 


\section{QALAAI ZANISTSCIENTIFIC JOURNAL \\ A Scientific Quarterly Refereed Journal Issued by Lebanese French University - Erbil, Kurdistan, Iraq \\ Vol. (5), No (4), Winter 2020 \\ ISSN 2518-6566 (Online) - ISSN 2518-6558 (Print)}

Naciscione A. (2005). Cognitive Aspects of Visual Representation of Phraseological Image. Phraseology 2005: The many faces of Phraseology: Proceedings of an interdisciplinary conference.Pp. 289-292.

Polishchuk N.V. (1988). Nominativniy status mezhdometnyh frazeologicheskih yedinits sovremennogo angliyskogo yazyka i osobennosti ih kontekstnogo upotrebleniya: AKD. Moskva: AST.

Vereshchagin Ye.M., Kostomarov V.G. (1983). Yazyk i kultura: Linguo-stranovedeniye $v$ prepodavanii russkogo yazyka kak inostrannogo. Moskva: AST.

Алехина, А. (2008). Idiomatic English. М: Высшая школа. (Alyohin, А. (2008). Idiomatic English. Moscow: Vissha Shkola).

Вежбицкая, А. (1996). Язык. Культура. Познание. М. : Высшая школа.

Комиссаров, В.Н. (2007). Теория перевода (лингвистические аспекты). М.: Высшая школа. (Komissarov, V. (2007). Teoriya Perevoda (lingvisticheskie aspekti). Moskow: Vissha Shkola).

Кунин, А.В. (2006). Курс фразеологии современного английского языка. М.: Высш. шк., Дубна: Изд. центр Феникс.

Селиверстова, О.Н. (2004). Труды по семантике. М.: Языки славянской культуры. Шаронов, И. А. (2002). Толкование эмоциональных междометий как знаков восприятия. Russian Linguistics. Volume 26 (Issue 26). Pp. 112-126.

\section{يـوختـه}

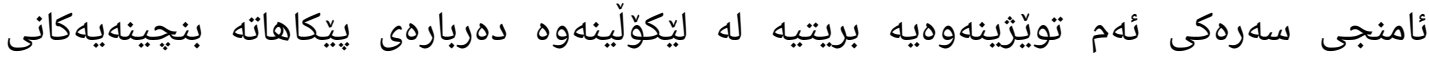
دهستهوازمناسيه، تايبهت به شيّوهزارى بنجينهى، رِهسنهكان .كه له نيّو وشه مانادارهكانى زمانياندا بهشيّكى دياريكراو ههيه تايبهت بهو دهربرينانهى كه دهست نيشان كراون له رِوانكهى رِنكه كانهوه . دلّنياكردنهوهى سهرهكى ئهنجامدراوه بوّ كردارى ليكولينه وه يه ك دهربارهى زانيارى دياريكراو بهبيردوّزهوه تايبهت بهم بابهته، كه ئهركى دياريكردنى رِوّلّ و ماناى كوّمهلَّيّك له دستوازه لهزمايّكدا، به رِهجاوكردنى رهنگ وهكو بهشيكى بنجينهى له كهلتوردا وهك سهرواتا له گرويى دهستهوازمكاندا، دهرخستن و ريّكخستنى ماناى كوّمهلّى دهستهوازه كه تايبهتن به هوّكارى ئهوهى رِنك تياياندا سهرواتاى دهربرينه كهيه.

$$
\text { رِنك بهشيّكى بايهخداره له زيانى تايبهتى تاكى هاوجهرخ. }
$$




\section{QALAAI ZANISTSCIENTIFIC JOURNAL}

A Scientific Quarterly Refereed Journal Issued by Lebanese French University - Erbil, Kurdistan, Iraq

Vol. (5), No (4), Winter 2020

ISSN 2518-6566 (Online) - ISSN 2518-6558 (Print)

زوّركات كهش، ههستهكان وه بكره تاكوو ريّكبوون و تهندروستى جهستهى خهلّكى يهيوهندى راستهوخوّى ههيه له گهلّ رِنكَكان .مروّق تايبهتى ئهوهى يهيداكردوه كه بهبردهوامى ناوبنى له ئامرازمكان و ديارده سروشتيهكانى دهورووبهرى وه له ئهنجامدا دهستكهوتنى شارهزاى تاكه كه، ميّزوويى وه كهلتورى.

كشت رِنكه جياوازهكانيه جيهان ناكريّ فهراموّش بكريّت .بوّيه، بوّ زمنناسان ناو لِّنان به هوّى رِنككان يهكيكه له به ناوبانكترين كروويهكانى وشهى واتادار .ههلوّيّهه جياوازهكان دهربارهى ئهو رِووكاره يان ئهوهيان، ييشاندراوه به شيّوازى رِوانبيزّى، شيّوهزارى وه ئهو ووتانهى كه له ناو

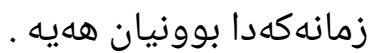

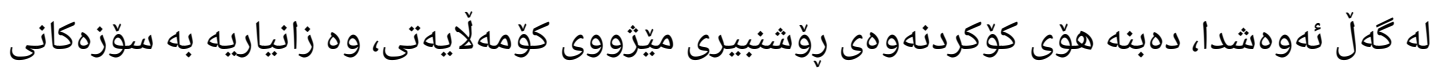
تايبهت به خسلّهى كهسيتى نهتهوهى. ئهم رِاستيانه هوّكارى ياساوى ههلِّزاردانى بابهتى ئهم تويّزينهوهيه، كه بابتيّكى يهيونديداره وه بايخداره.

\section{الملخص}

يهدف هذا البحث إلى دراسة الوحدات اللغوية (التعابير) التي تحتوي في دلالاتها على عنصر تسمية اللون. يتم

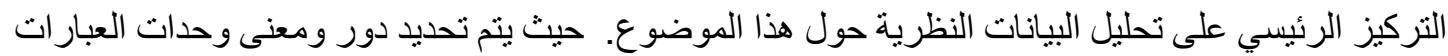

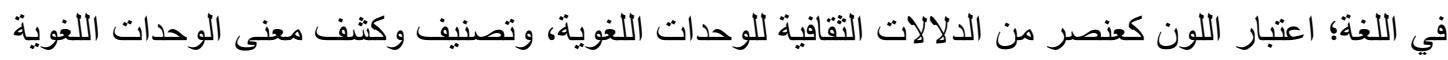
بمكون تعيين اللون.

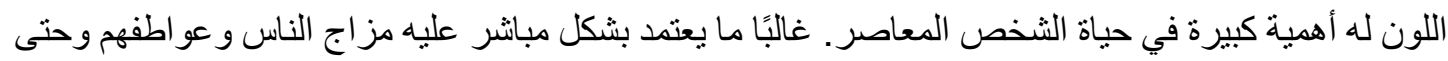

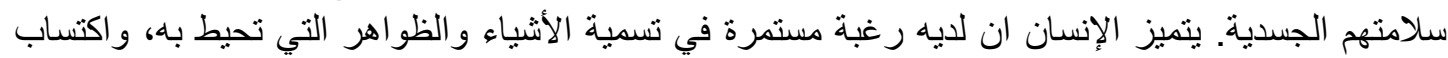

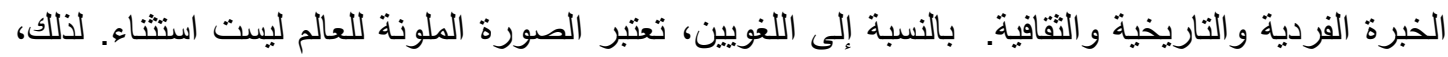

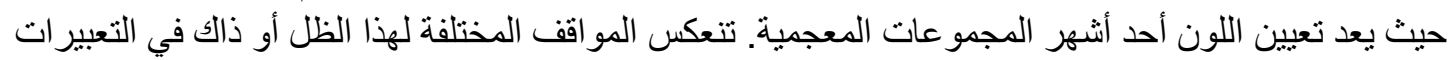
التصويرية والتعابير والأقوال الموجودة في اللغة. فهم يجمعون المعلومات الاجتماعية والتاريخية والفكرية 


\section{QALAAI ZANISTSCIENTIFIC JOURNAL}

A Scientific Quarterly Refereed Journal Issued by Lebanese French University - Erbil, Kurdistan, Iraq

Vol. (5), No (4), Winter 2020

ISSN 2518-6566 (Online) - ISSN 2518-6558 (Print)

و العاطفية ذات الطابع الوطني المحدد. هذه الافكار هي التي ساهمت في تحديد واختيار موضوع هذا البحث لأهميتها المتعلقة. 